\title{
A short survey on the common Doctrines Between the Bektashi order and Shi'a Islam
}

SeyedAmirHossein Asghari ${ }^{1}$

${ }^{1}$ Affiliation not available

January 15, 2021

\section{Hosted file}

On_the_Common_Doctrines_Between_the_Bekt.pdf available at https://authorea.com/users/385880/ articles/504227-a-short-survey-on-the-common-doctrines-between-the-bektashi-order-andshi-a-islam 